\title{
A comparative study of online learning in response to the coronavirus disease 2019 pandemic versus conventional learning
}

Safaa M. Hanafy, MD, Mohammad I. Jumaa, MD, Mostafa A. Arafa, MD.

\begin{abstract}
الأهداف : استكشاف موقف وتصور طلاب وأعضاء هيئة تدريس كلية الطب الطب التباء

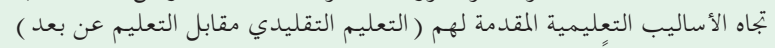

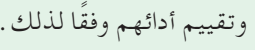

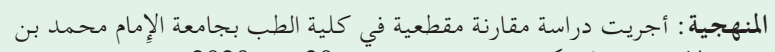

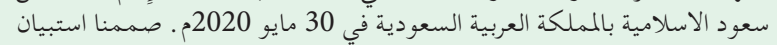

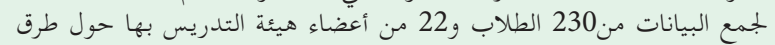

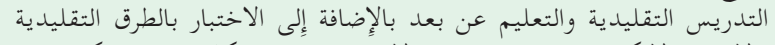

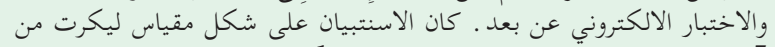

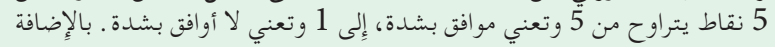

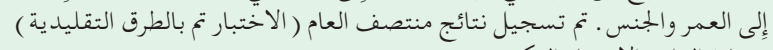

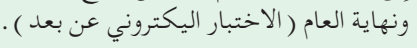

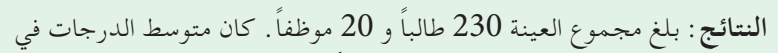

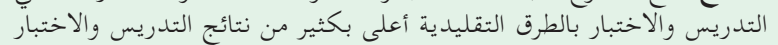

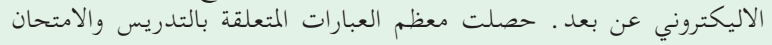

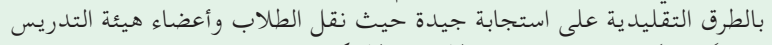

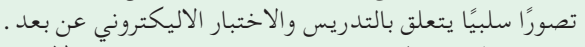

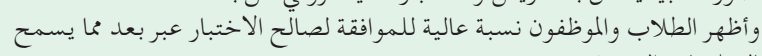

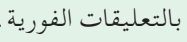

الخلاصة : التدريس بالطرق التقليدية أكثر فاعلية، ويمكن الوصول إِليه، كما أنه إنها

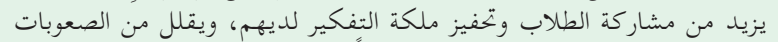

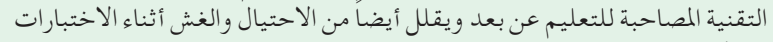

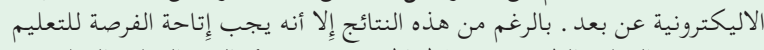

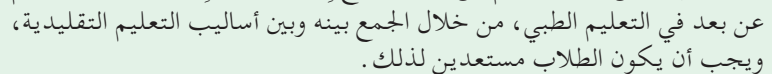

Objectives: To explore the attitude and perception of undergraduate medical students and their staff towards the educational methods (conventional versus online) and to assess their performance accordingly.

Methods: It was a comparative cross sectional study, conducted at the Faculty of Medicine, Al- Imam University, Riyadh, Saudi Arabia on May 30, 2020. A structured questionnaire was designed to collect the data from students and staff about conventional teaching, online teaching, conventional examination and online examination. It was in the form of 5-point Likerttype scale ranging from 5-strongly agree, to 1-strongly disagree, in addition to age and gender. The results of conventional and online examination were recorded.
Results: The total sample reached 230 students and 20 staff. Mean scores for conventional teaching and examination were significantly higher than online. The mean values for grades of online final examination was significantly higher than those of midterm conventional examination. Most of the statements related to conventional teaching and examination attained a good response where students and their staff conveyed a negative perception pertinent to online examination. Students and staff showed a higher percentage of agreement in favor of online examination allowing immediate feedback.

Conclusion: Conventional teaching was perceived as more effective, accessible, less technical difficulties and less fraud and cheating. Online learning, should be allowed in undergraduate medical education, by combining it with conventional learning, and students should be prepared to it.

Keywords: ordinary and online teaching, basic medical science, college of medicine, COVID 19

Saudi Med J 2021; Vol. 42 (3): 324-331

doi: 10.15537/smj.2021.42.3.20200741

From the Department of Anatomy (Hanafy, Jumaa), Faculty of Medicine, Al-Imam Mohammad Bin Saud Islamic University; from the Cancer Research Chair, Faculty of Medicine (Arafa), King Saud University Riyadh, Kingdom of Saudi Arabia; and from the Department of Anatomy (Jumaa), Faculty of Medicine, Al-Azhar University, Asuit, Egypt.

Received 19th November 2020. Accepted 9th February 2021.

Address correspondence and reprint request to: Dr. Safaa M. Hanafy, Assistant Professor, Department of Anatomy, Faculty of Medicine, Al-Imam Mohammad Bin Saud Islamic University, Riyadh, Kingdom of Saudi Arabia.E-mail: aabdelaziz@imamu.edu.sa

ORCID ID: http://orcid.org/0000-0003-4590-839X

Disclosure. Authors have no conflict of interests, and the work was not supported or funded by any drug company. 
$\mathrm{T}$ The rise and spread of the severe acute respiratory syndrome coronavirus 2 virus, have driven a public health crisis, the 2019 novel coronavirus (COVID-19) epidemic, to debilitate nations worldwide. ${ }^{1}$ Coronavirus-19 originally appeared in Wuhan, China, which led authorities to bolt the city down to reduce the chance of further disease transmission. ${ }^{2}$ Within some weeks; however, cases of COVID-19 were discovered in numerous other nations and became a worldwide risk by early $2020 .^{3}$ The World Health Organization (WHO) later announced that the outbreak was a pandemic on March 11, 2020. ${ }^{4}$ In reaction to the COVID-19 widespread, government authorities have taken different measures to avoid or diminish the spread of epidemic. ${ }^{5}$ At least 150 nations have closed schools and instructive educate across the nation, affecting over $80 \%$ of the world's understudy population. ${ }^{6}$ In specific, the COVID-19 pandemic forced colleges to move their entire instructional apparatus to one of online delivery overnight. ${ }^{7}$ The benefits of online or electronic learning have been archived by numerous companies, colleges, employees, and students alike. Online learning has been advanced as being more fetched viable and helpful than conventional instructive situations as well as giving openings for more learners to proceed their instructions. However, is online learning truly more compelling

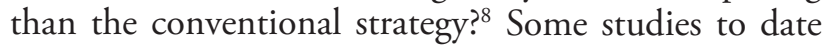
have compared students' performance in response to online versus conventional learning. Kemp and Grieve, ${ }^{9}$ explored whether students' academic grades and favorites for learning psychology varied depending on whether it was carried online or offline, their results showed that students had a general preference for face to face activities, even predominantly when the discussion of academic topics was required. However, no obvious differences were found in academic performance during online learning compared to face to face classroom learning. To the best of our knowledge, this is one of the first investigations, particularly in our region, that aimed to compare the attitudes and opinions of undergraduate medical students and their staff with regard to the ordinary in-person college learning and online learning and to assess their performance in each context accordingly.

Methods. This was a comparative cross-sectional study conducted at the Faculty of Medicine, Al-Imam University, Saudi Arabia. After gaining permission from the institutional review board, students and staff were invited to participate in the study, with the rationale and objectives of the study explained in detail to each prospective participant prior to study inclusion.
The study was conducted among students of the Human Body II course, which introduces participants to 5 important systems in the human body, namely, the digestive, urinary, male and female pelvic, male and female perinea, and endocrine systems. This course is integrated together with other classes on the structure, function of such systems (anatomy and physiology) and the main biochemical pathways involved (Biochemistry). The course is taught using a range of interactive lectures, laboratory sessions, and seminars.

In-person college learning. The Human Body II course began on January 19, 2020 with the study of the digestive system taught through conventional in-person learning at the college for 7 weeks (with 3 lectures, one laboratory session, and one seminar held per week).

The anatomy labs were covered through learning on cadavers, plastinated specimens and anatomy table. Regarding seminars, the students in were divided into groups, where each group adopted a specific objective and presented it to a staff member, who evaluated the students immediately after their presentations (namely, the seminars were conducted in the classroom of the college).

On the intended day of the exam scheduled for March 8, 2020, students were examined according to the previous objectives 1 to 4 via multiple-choice questions and objective structured practical examinations (OSPEs) conducted in the college. As previously noted; however, the COVID-19 pandemic ultimately forced Al-Imam University, Saudi Arabia to switch their entire instructional apparatus to online learning on March, 14, 2020. Thus, the rest of the Human Body II course was conducted online for the remaining 7 weeks of its run, with the staff members and students given training on how to register for the Zoom video-conferencing application (Zoom Video Communications, San Jose, CA, USA) through an orientation program conducted by the college. The anatomy labs were covered through learning on line videos and figures from anatomy textbooks. The histology labs were covered through learning on figures from histology textbooks. Thus, on the intended day of the exam scheduled for April 29, 2020, the students were examined through written (multiple-choice questions) assessments and OSPEs conducted online. The students were asked to keep their laptops fully charged and open the Website (https:// imammedaeu.org/) and to keep the device awake so that marks could be automatically generated at the end of the test and students could view their correct and incorrect answers.

For this investigation, a structured questionnaire was designed to collect data from students and staff. 
Responses were requested according to a 5-point Likert scale $(5=$ strongly agree, $4=$ agree, $3=$ uncertain, $2=$ disagree, and $1=$ strongly disagree). In addition to age and gender, students and their staff were asked about their opinions and attitudes regarding conventional teaching, online teaching, and the conventional and online examination formats. The results of the mid-year (conventional) and end of year (online examination) assessments were recorded.

The conventional teaching and online teaching questionnaires were composed of the same 10 questions, while the conventional examination and online examination questionnaires were composed of the same 5 questions. We did the pilot study on 13 subjects in each group and the result of Cronbach's alpha was nearly the same (0.8 and 0.76).

Statistical analysis. The data was entered and analyzed using IBM SPSS Statistics, Version 22.0. Frequency distribution was recorded for each variable and the mean values of quantitative variables were compared using the t-test. Proportions were compared using the Chi-squared test. The p value was set at 0.05 .

Results. A total of 230 students were included in the study, ranging in age from 19 to 23 years. Most participants were male $(72.2 \%)$ and three-quarters $(74.8 \%)$ were in grade 1 .

Table 1 shows the mean scores for the comparisons of conventional teaching versus online teaching and conventional examination versus online examination, respectively. Students' attitudes generally trended more positively in favor of conventional teaching than online teaching $(70.8 \%$ versus $63.6 \%)$, with the mean score of interest in conventional teaching being significantly higher than that for online teaching $(35.4 \pm 7$ versus $31.8 \pm 8.3$ points; $\mathrm{t}=6.1 ; p=0.001)$. Similarly, the mean score for conventional examination was slightly higher than that for online examination $(16.2 \pm 3.4$ versus $15 \pm 3.8$ points; $\mathrm{t}=4.7 ; p=0.001$ ). In comparison with female students, male students displayed more positive attitudes toward conventional teaching (mean score: $33.8 \pm 7.3$ versus $36.1 \pm 6.8$ points; $\mathrm{t}=2.1 ; p=0.03)$ than online examination (mean score: $14.2 \pm 3.4$ versus 15.3 $\pm 3.9 ; \mathrm{t}=2 ; p=0.04$ ). Finally, no significant difference was detected with regard to gender between the mean scores for online teaching $(30.7 \pm 6$ versus $32.1 \pm 6.5$ points; $\mathrm{t}=1.1 ; p=0.2)$ and conventional examination $(16 \pm 3.7$ versus $16.2 \pm 3.3$ points; $\mathrm{t}=0.4 ; p=0.9)$.

The 2 scoring categories of "strongly agree" and "agree" for all scales' statements were combined and their distribution is shown in Tables 2 \& 3. A nearly similar response for both methods of teaching was
Table 1 - Comparison of the student's scores means for the scales: conventional teaching and examination versus online teaching and examination.

\begin{tabular}{lccc}
\hline Scales & $\begin{array}{c}\text { Scale } \\
\text { mean } \pm \text { SD }\end{array}$ & Paired t & $P$-value \\
\hline Conventional teaching & $35.4 \pm 7$ & 6.1 & 0.001 \\
Online teaching & $31.8 \pm 8.3$ & & \\
Conventional examination & $16.2 \pm 3.4$ & 4.7 & 0.001 \\
Online examination & $15 \pm 3.8$ & & \\
\hline
\end{tabular}

recorded for the statement "the respondents received enough training to be able to use computer programs and skills" (50.9\% versus 50.4\%). For the remaining statements, a significant and greater discrepancy in favor of conventional teaching was noted, with students expressing more negative attitudes toward online teaching, particularly for those statements pertaining to student collaboration and teamwork, students' behaviors, brainstorming and critical thinking, and a sense of guidance and support $(p=0.001)$. Meanwhile, students had negative attitudes related to participating in community activities and conducting volunteer work during curfew in relation to both conventional teaching and online teaching ( $46.1 \%$ versus $26.1 \%)$. One statement garnered a higher percentage of students who agreed that online teaching improved time usage and decreased the amount of time lost in comparison with conventional teaching (61.3\% versus $47.8 \%$; $p=0.003)$. Conversely, 2 statements garnered a higher percentage in favor of online examinations in comparison with conventional examinations, namely, being able to receive immediate feedback after an examination (48.3\% versus $40 \%$ ) and a greater risk of cheating and/or fraud ( $42.6 \%$ versus $21.7 \%$ ), yet only the latter result was significant $(p=0.001)$. All other statements showed a significantly greater percentage in favor of conventional examinations, particularly with respect to the presence of a sufficient time limit $(49.6 \%$ versus 14.3\%) (Table 3).

The mean values for grades of the online final examination were significantly higher than those of midterm conventional examination $(77.7 \pm 13$ versus $74.9 \pm 15.7$ points; $\mathrm{t}=2.8 ; p=0.006$ )

Staff results. A total of 22 staff members agreed to participate in the study, more than half $(63.6 \%)$ of whom were assistant professors, associate professors and full professor were $12.5 \%$ each, the remaining percentage $(11.7 \%)$ were lecturers. Male participants composed $72.7 \%$ of the study's staff population. A comparison of total score mean values is presented in Table 4 . The 
Table 2 - Distribution of students scales' statements for conventional teaching versus online teaching.

\begin{tabular}{|c|c|c|c|c|}
\hline Conventional Teaching & n (\%) & Online Teaching & n (\%) & $P$-value \\
\hline $\begin{array}{l}\text { Do you receive enough training for using the online } \\
\text { learning programs and improve your computer } \\
\text { skill? }\end{array}$ & $117(50.9)$ & $\begin{array}{l}\text { Do you receive enough training for using online } \\
\text { learning to improve your computer skills during } \\
\text { online teaching }\end{array}$ & $116(50.4)$ & 0.9 \\
\hline $\begin{array}{l}\text { Do you have easy internet access to collect reliable } \\
\text { information (learning resources) using technology? }\end{array}$ & $162(70.4)$ & $\begin{array}{l}\text { Do you have easy internet access to collect } \\
\text { information (learning resources) using technology } \\
\text { in your college? }\end{array}$ & $145(63.0)$ & 0.09 \\
\hline $\begin{array}{l}\text { Do you think conventional teaching improve } \\
\text { the student collaboration and share in teamwork } \\
\text { actions on the assigned tasks? }\end{array}$ & $132(57.4)$ & $\begin{array}{l}\text { Do you think online teaching improve the student } \\
\text { collaboration and share in teamwork actions on } \\
\text { the assigned tasks? }\end{array}$ & $90(39.1)$ & 0.001 \\
\hline $\begin{array}{l}\text { Do the ordinary attended college learning improve } \\
\text { student mode } \& \text { make the education behavior } \\
\text { better? }\end{array}$ & $140(60.9)$ & $\begin{array}{l}\text { Do online teaching improve student mode and } \\
\text { make education behavior better? }\end{array}$ & $90(39.1)$ & 0.001 \\
\hline $\begin{array}{l}\text { Do the conventional teaching improve } \\
\text { brainstorming and critical thinking? }\end{array}$ & $122(53.0)$ & $\begin{array}{l}\text { Do online teaching improve brainstorming and } \\
\text { critical thinking? }\end{array}$ & 77 (33.5) & 0.001 \\
\hline $\begin{array}{l}\text { Do the conventional teaching increase the student's } \\
\text { sense of guidance and support? }\end{array}$ & $131(57.0)$ & $\begin{array}{l}\text { Do online teaching increase the student's sense of } \\
\text { guidance and support? }\end{array}$ & $90(39.1)$ & 0.001 \\
\hline $\begin{array}{l}\text { Do the ordinary attended college learning help in } \\
\text { solving of administration problems? }\end{array}$ & $128(55.7)$ & $\begin{array}{l}\text { Do online teaching help in solving of the } \\
\text { administration problems? }\end{array}$ & $74(32.2)$ & 0.001 \\
\hline $\begin{array}{l}\text { Do the conventional teaching improve the student } \\
\text { share in teaching and student activities? }\end{array}$ & $137(59.7)$ & $\begin{array}{l}\text { Do online teaching improve the student shares in } \\
\text { teaching and student activities? }\end{array}$ & $82(35.7)$ & 0.001 \\
\hline $\begin{array}{l}\text { Do the conventional teaching improve student } \\
\text { shares in community activities and volunteer work } \\
\text { during curfew? }\end{array}$ & $106(46.1)$ & $\begin{array}{l}\text { Do online teaching improve the student shares in } \\
\text { community activities and volunteer work during } \\
\text { curfew? }\end{array}$ & $60(26.1)$ & 0.001 \\
\hline $\begin{array}{l}\text { Do the conventional teaching improve the time } \\
\text { consuming and decrease the time lost? }\end{array}$ & $110(47.8)$ & $\begin{array}{l}\text { Do online teaching improve the time consuming } \\
\text { and decrease the time lost? }\end{array}$ & $141(61.3)$ & 0.001 \\
\hline
\end{tabular}

Table 3 - Distribution of student's scales' statements for conventional examination versus online examination.

\begin{tabular}{|c|c|c|c|c|}
\hline Conventional exam & n $(\%)$ & Online exam & n $(\%)$ & $P$-value \\
\hline Do you think conventional exams easy to access? & $167(72.6)$ & Do you think the online exams easy to access? & $144(62.6)$ & 0.02 \\
\hline $\begin{array}{l}\text { Do you think conventional exams get immediate } \\
\text { feedback? }\end{array}$ & $92(40.0)$ & $\begin{array}{l}\text { Do you think the online exams get immediate } \\
\text { feedback? }\end{array}$ & $111(48.3)$ & 0.07 \\
\hline $\begin{array}{l}\text { Do you think that the conventional exams have a } \\
\text { sufficient time limit? }\end{array}$ & $114(49.6)$ & $\begin{array}{l}\text { Do you think the online exams have a sufficient time } \\
\text { limit? }\end{array}$ & $33(14.3)$ & 0.001 \\
\hline $\begin{array}{l}\text { Do you agree that time was not wasted once the test was } \\
\text { started since it had to be completed within a set time? }\end{array}$ & $104(45.2)$ & $\begin{array}{l}\text { Do you agree that time was not wasted once the test } \\
\text { was started since it had to be completed within a set } \\
\text { time? }\end{array}$ & $71(30.9)$ & 0.001 \\
\hline $\begin{array}{l}\text { Do you think the risks of cheating and fraud would be } \\
\text { higher in conventional exams? }\end{array}$ & $50(21.7)$ & $\begin{array}{l}\text { Do you think the risks of cheating and fraud would be } \\
\text { higher in online exams? }\end{array}$ & $98(42.6)$ & 0.001 \\
\hline
\end{tabular}


staff attitude was significantly in favor of conventional teaching (41.8 \pm 6.3 points) in comparison with online teaching $(33.6 \pm 74$ points; $\mathrm{t}=3.3 ; p=0.003)$. On the other hand, the attitude toward online examinations was significantly better than that toward conventional examinations $(19.4 \pm 3$ versus $16.8 \pm 2.4$ points; $\mathrm{t}=$ 2.6; $p=0.01$ ).

The 2 scoring categories of "strongly agree" and "agree" for all scales' statements were combined and their distribution is shown in Tables 5 and 6. Staff participants showed a higher percentage in favor of

Table 4 - Comparison of the staff scores' means for the scales: conventional teaching and examination versus online teaching and examination.

\begin{tabular}{lccc}
\hline Scales & $\begin{array}{c}\text { Scale } \\
\text { mean } \pm \text { SD }\end{array}$ & Paired t & $P$-value \\
\hline Conventional teaching & $41.8 \pm 6.3$ & 3.3 & 0.003 \\
$\begin{array}{l}\text { Online teaching } \\
\begin{array}{l}\text { Conventional } \\
\text { examination }\end{array}\end{array}$ & $19.4 \pm 74$ & & \\
Online examination & $16.8 \pm 2.4$ & & 0.01 \\
\hline
\end{tabular}

conventional teaching for all statements, ranging in value from $77.3 \%$ (improvement of students' modes and behaviors and enhancement of students' skills and development) to $95.5 \%$ (usage of different varieties of teaching strategies). The lowest percentage difference was noted for the statement that conventional teaching mitigates the time-consuming nature of and decreases the time lost to education (6\%). A significant difference was detected regarding all statements about online teaching in comparison with conventional teaching, particularly concerning the length of teaching, improvements in students' modes and behaviors, and enhancement of students' skills and development. Two statements garnered nearly the same level of expectation from staff between conventional and online teaching (namely, providing immediate, constructive feedback to students [68.2\% versus $72.7 \%$ ] and improving the time-consuming nature of and decreasing the time lost to education [63.6\%versus 59.1\%]) (Table 5).

Regarding examinations, college staff members were in favor of conventional examinations to a significant degree, except regarding the 2 statements concerning the reception of immediate feedback after an examination (31.8\% versus $90.9 \% ; p=0.001)$ and the risk of cheating and/or fraud (9.1\% versus $86.4 \%$; $p=0.001$ ) (Table 6).

Table 5 - Distribution of staff scales' statements for conventional teaching versus online teaching.

\begin{tabular}{|c|c|c|c|c|}
\hline Conventional teaching & n $(\%)$ & Online teaching & n (\%) & $P$-value \\
\hline $\begin{array}{l}\text { I am available to my students in the college on a } \\
\text { regular basis for questions and assistance. }\end{array}$ & $20(90.9)$ & $\begin{array}{l}\text { I am online available to my students on a regular basis } \\
\text { for questions and assistance. }\end{array}$ & $16(72.7)$ & 0.001 \\
\hline $\begin{array}{l}\text { I use a variety of teaching strategies in the college to } \\
\text { help my students learn. }\end{array}$ & $21(95.5)$ & $\begin{array}{l}\text { I use a variety of online teaching strategies to help my } \\
\text { students learn. }\end{array}$ & $15(68.2)$ & 0.001 \\
\hline $\begin{array}{l}\text { I provide immediate, constructive feedback to } \\
\text { students about assignments and questions. }\end{array}$ & $15(68.2)$ & $\begin{array}{l}\text { I provide immediate, constructive feedback to students } \\
\text { about assignments and questions. }\end{array}$ & $16(72.7)$ & 0.29 \\
\hline I enjoy conventional teaching approaches & $20(90.9)$ & I enjoy trying new online teaching approaches & $13(59.1)$ & 0.001 \\
\hline $\begin{array}{l}\text { I communicate my expectations about } \\
\text { participation, behavior, and work quality to my } \\
\text { students }\end{array}$ & $21(95.5)$ & $\begin{array}{l}\text { I communicate my expectations about participation, } \\
\text { behavior, and work quality to my students. }\end{array}$ & $13(59.1)$ & 0.001 \\
\hline $\begin{array}{l}\text { I expect conventional teaching to take more time } \\
\text { than online teaching instruction, and I am prepared } \\
\text { for it. }\end{array}$ & $18(81.8)$ & $\begin{array}{l}\text { I expect online teaching to take more time than face-to- } \\
\text { face instruction and I am prepared for it. }\end{array}$ & $4(18.2)$ & 0.001 \\
\hline $\begin{array}{l}\text { Do you think conventional teaching improve the } \\
\text { student collaboration and share in teamwork actions } \\
\text { on the assigned tasks? }\end{array}$ & $17(77.3)$ & $\begin{array}{l}\text { Do you think online teaching improve the student } \\
\text { collaboration and share in teamwork actions on the } \\
\text { assigned tasks? }\end{array}$ & $8(36.4)$ & 0.001 \\
\hline $\begin{array}{l}\text { Do conventional teaching improve student mode } \\
\text { and make educational behavior better? }\end{array}$ & $17(77.3)$ & $\begin{array}{l}\text { Do online teaching improve student mode and make } \\
\text { educational behavior better? }\end{array}$ & $4(18.2)$ & 0.001 \\
\hline $\begin{array}{l}\text { Do the conventional teaching improve student skills } \\
\text { and their development? }\end{array}$ & $20(90.9)$ & $\begin{array}{l}\text { Do online teaching improve student skills and their } \\
\text { development? }\end{array}$ & $5(22.7)$ & 0.001 \\
\hline $\begin{array}{l}\text { Do the conventional teaching improves the time } \\
\text { consuming and decrease the time lost? }\end{array}$ & $14(63.6)$ & $\begin{array}{l}\text { Do online teaching improve the time consuming and } \\
\text { decrease the time lost? }\end{array}$ & $13(59.1)$ & 0.3 \\
\hline
\end{tabular}


Table 6 - Distribution of staff scales' statements for conventional examination versusonline examination.

\begin{tabular}{|c|c|c|c|c|}
\hline Conventional exam & n $(\%)$ & Online exam & n $(\%)$ & $P$-value \\
\hline Do you think conventional exams easy to access? & $18(81.8)$ & Do you think the online exams easy to access? & $12(54.5)$ & 0.04 \\
\hline $\begin{array}{l}\text { Do you think conventional exams get immediate } \\
\text { feedback? }\end{array}$ & $7(31.8)$ & $\begin{array}{l}\text { Do you think the online exams get immediate } \\
\text { feedback? }\end{array}$ & $20(90.9)$ & 0.001 \\
\hline $\begin{array}{l}\text { Do you think the conventional exams have a sufficient } \\
\text { time limit? }\end{array}$ & $20(90.9)$ & $\begin{array}{l}\text { Do you think the online exams have a sufficient } \\
\text { time limit? }\end{array}$ & $14(63.6)$ & 0.03 \\
\hline $\begin{array}{l}\text { Do you agree that time was not wasted once the test was } \\
\text { started since it had to be completed within a set time? }\end{array}$ & $17(77.3)$ & $\begin{array}{l}\text { Do you agree that time was not wasted once } \\
\text { the test was started since it had to be completed } \\
\text { within a set time? }\end{array}$ & $11(50.0)$ & 0.06 \\
\hline $\begin{array}{l}\text { Do you think the risks of cheating and fraud would be } \\
\text { higher in conventional exams? }\end{array}$ & $2(9.1)$ & $\begin{array}{l}\text { Do you think the risks of cheating and fraud } \\
\text { would be higher in online exams? }\end{array}$ & $19(86.4)$ & 0.0001 \\
\hline
\end{tabular}

Discussion. The advent of online education under the current circumstances of the COVID-19 pandemic has enabled students to continue to obtain a quality education at home. The results of the current study suggest significant positive and greater degrees of student interest are felt toward conventional teaching in comparison with online teaching. These results are in line with some authors who found that a steady number of students chosen not to participate in an online electrocardiogram course but rather continue to attend the face-to-face classes, in spite of the fact that the substance of both was indistinguishable. ${ }^{10}$ On the other hand, Pei and $\mathrm{Wu}^{11}$ test the effectiveness of online and offline courses by comparing the results before and after the test, and the results of the retention tests in 16 articles between 2000 and 2017, they did not report significant data between the 2 teaching strategies in 7 articles and there was a significant advancement in the online study groups in 9 articles.

In comparison with female students in the current study, male students presented better attitudes toward conventional teaching and online examination, in agreement with the results of Pei and $\mathrm{Wu}^{11}$ who found that the effectiveness of online or offline courses for medical students might be impacted by the characteristics of the understudies themselves, such as gender and attitude. ${ }^{12}$

Students in our study expressed negative attitudes concerning online teaching including particularly when asked to score statements pertinent to student collaboration and teamwork, improvement of their modes and behaviors, enhancing of brainstorming and critical thinking, and their sense of guidance and support. These results were supported by Bali and $\mathrm{Liu}^{8}$ who reported that face to-face learning recognition was higher than distance learning in term of social nearness, social interaction, and fulfillment. Also, Salcedo ${ }^{13}$ mentioned that online teaching hampers the learning process as the students often have to limit their questions to blurb and then give the teacher and classmates time to answer.

The negative attitudes toward successfully participating in community activities and performing volunteer work during curfew was apparent for both conventional and online teaching, emphasizes the need to include the specific content of a pandemic/crisis in the current curriculum. However, few universities to date have embedded pandemic preparedness or disaster medicine training into undergraduate training. ${ }^{14}$ Ragazzoni et $\mathrm{al}^{15}$ conducted a research study on disaster medicine qualifications and found that one in 10 students had heard of disaster medicine, in contrast to the majority of those who had received such training.

One statement that attracted a higher percentage of students to agree with, is related to online teaching and its relation to the improvement of time consumption and decreasing the amount of time lost, in comparison to conventional teaching. The current results agrees with Van de Vord and Pogue ${ }^{16}$ who reviewed the teacher's 6-week time record set online and on campus during a 16-week semester, they found that the total teaching time, per week, per student spent by face-toface teachers was longer (average: 14.98 minutes) than online (average: 12.70 minutes), suggesting that more time was spent teaching face-to-face. Also, Amir et al ${ }^{17}$ pointed to assess the understudy viewpoint of online learning versus face to face learning in undergraduate dentistry curriculum. They found that students felt to have more learning time in online learning.

Both students and staff showed a higher percentage of agreement in favor of online examinations allowing immediate feedback after the examination, yet carrying 
a greater risk of cheating and fraud. Elsewhere, Kumar et $\mathrm{al}^{18}$ assessed perceptions of the advantages and disadvantages of electronic assessment among first-year medical students engaged in online learning. Among the advantages, students said that they were being exposed to new ways of learning and obtaining immediate results/ feedback. Meanwhile, the disadvantages mentioned by the students were: power and electricity breakdowns can impede the learning process and some students misused the opportunity to copy from friends. Along these lines, Watson and Sottile ${ }^{19}$ examined 635 undergraduate and graduate students for cheating behaviors in both types of classes (on-line and face to face) at a medium-sized university and found that it very difficult to make sure that students did not cheat on online exams.

Notably, the means of grade value for the online final examination in this study were significantly higher than that of the midterm conventional examination. Although these results were contradictory to the perceptions of the students, such results could be explained by an increase in cheating and fraud, which might have been more frequent during the online exam than the conventional exam. In contrast with our results, Bettinger et $\mathrm{al}^{20}$ conducted a study to evaluate the impact of online learning and direct learning on student progress and achievement, and found that students did not perform well in online courses. Similarly, LorenzoAlvarez et $\mathrm{al}^{21}$ revealed that training in radiology on an online learning platform yields the same learning outcomes as we see face-to-face.

The present study revealed that the mean score for staff attitudes and perceptions was significantly higher in favor of conventional teaching and examination in comparison to online teaching and examination. These results explain online college degrees are not much favored by Arab Academia teachers as criteria to be acknowledged in universities for work or further university studies. ${ }^{22}$ Pei and $\mathrm{Wu}^{11}$ have explained that future recruitment executives view the online education system as a cheaper and easier way to gain understanding, often citing poor training ideas, unsupervised tests and electrical studies as a waste to the learning process.

The results of Parker et $\mathrm{al}^{23}$ concluded that $51 \%$ of college presidents proposed that online courses provide equal value as compared with face-to-face courses, whereas as it were $29 \%$ of the open proposed online courses offer the same esteem.

Our staff expressed a higher percentage of positive attitudes toward conventional teaching for many statements in comparison to the online one, such as the capacity to improve student modes and behaviors as well as enhance their skills and development; the usage of different varieties of teaching strategies; and the ability to communicate expectations about participation, behavior, and work quality to the students. Similar results were reported by Esani, ${ }^{24}$ who said that instructors have more regular contact with students in conventional learning through class discussions, laboratory exercises, and oral and written exams, and are able to assess their previous learning and current level of cognitive knowledge during each class by varying means including relying on a series of discrete visual cues. On the other hand, Chiasson et $\mathrm{al}^{25}$ observed that faculty members felt that developing an online course requires more time than developing a classroom course. Most of the participants said that it takes a long time to learn the technology and put the content on the course site.

The negative results that were observed with online learning (in response to Covid19) in the current study were anticipated by some specialists who said that the COVID-19 widespread would unfavorably affect online instruction for some reasons. ${ }^{26}$ Firstly, they felt that the move to online instruction can be challenging, in fact when the transitioning plan is given adequate time. ${ }^{24}$ Other than, amid the COVID-19 widespread, there's not a single parcel of the economy that has been unaffected.

Study limitations. The limitations of the study centered on sample, and student skills/abilities. Our sample have been drawn from a single institute, which cast a shadow on the generalizability of the results. Secondly, data collection relied on self-reported actions that may not always be objective. However, most studies examining higher education students' self-assessments recommend that self-assessments and actual skills are positively correlated, and social desirability bias does not play a key role in student responses to cognitive and behavioral surveys. Future research should also investigate combined teaching methods for course effectiveness.

In conclusion, despite the urgent need for online learning especially in emergencies like pandemics, our medical students and the teaching staff expressed negative impressions for online education. Students were not prepared to the sudden shift from conventional to online education, their responses were in favor to conventional teaching. Broadly, online instruction turns students into passive observers rather than active participants. However, it should be allowed in undergraduate medical education, but, to maximize the benefits, it is advisable to combine both online and conventional learning methods ("blended learning") and proactively strive to mitigate the unique challenges that could be encountered with online courses through the 
introduction of simple solutions such as more training on online teaching, dividing the course into several parts that can be completed in a short amount of time, and fostering personal interactions within the online world or promoting the use of social media during the training, thus providing additional opportunities for social interaction.

Acknowledgment. The authors thank the dean of scientific research at King Saud University, Riyadh, Saudi Arabia for funding through the vice dean of the scientific research chair.

\section{References}

1. Singha T. A Review of Coronavirus Disease-2019 (COVID-19). Indian J Pediatr 2020; 87: 281-286.

2. Xiang YT, Yang Y, Li W, Zhang L, Zhang Q, Cheung T, et al. Timely mental health care for the 2019 novel coronavirus outbreak is urgently needed. Lancet Psychiatry 2020; 7: 28-29.

3. Spina S, Marrazzo F, Migliari M, Stucchi R, Sforza A, Fumagalli $\mathrm{R}$. The response of Milan's emergency medical system to the COVID-19 outbreak in Italy. Lancet 2020; 395 (10227): e49-e50.

4. World Health Organization. Coronavirus Disease 2019 (COVID-19) Situation Report-51. [cited 2020] Available from: https:/www.who.int/docs/defaultsource/ coronaviruse/situation-reports/20200311-sitrep-51-covid 19.pdf?sfvrsn=1ba62e $57 \_10$

5. Bedford J, Enria D, Giesecke J, Heymann D L, Ihekweazu C, Kobinger G, et al. Towards controlling of a pandemic. Lancet 2020; 395 (10229): 1015-1018.

6. UNESCO. COVID-19 Educational disruption and response. [cited 2020] Available from: https://en.unesco.org/themes/ education-emergencies/coronavirus-school-closures.

7. Liguori E, Winkler C. From Offline to Online: Challenges and Opportunities for Entrepreneurship Education Following the COVID-19 Pandemic. Entrepreneurship Education and Pedagogy 2020; 3: 346-351.

8. Bali S, Liu MC. Students' perceptions toward online learning and face-to-face learning courses2018. Conf Series 2018; 1108: 012094.

9. Kemp N, Grieve R. Face-to-face or face-to-screen? Undergraduates' opinions and test performance in classroom vs. online learning. Front Psychol 2014; 5: 1278.

10. Keis O, Grab C, Schneider A, Öchsner W. Online or face-toface instruction? A qualitative study on the electrocardiogram course at the University of Ulm to examine why students choose a particular format. BMC Medical Education 2017; 17: 194.

11. Pei L, Wu H. Does online learning work better than offline learning in undergraduate medical education? A systematic review and meta-analysis. Med Educ Online 2019; 24: 1666538.

12. Omar ND, Hassan H, Atan H. Student engagement in online learning: learners' attitude toward E-mentoring. Procedia Soc Behav Sci 2012; 67: 464-475.
13. Salcedo CS. Comparative analysis of learning outcomes in faceto-face foreign language classes vs. language lab and online. $J$ Coll Teach Learn 2010; 7: 43-54.

14. O’Byrne L, Gavin B, McNicholas F. Medical students and COVID-19: the need for pandemic preparedness. J Med Ethics 2020; 46: 623-626.

15. Ragazzoni L, Ingrassia PL, Gugliotta G, Tengattini M, Franc JM, Corte FD. Italian medical students and disaster medicine: awareness and formative needs. Am J Disaster Med 2013; 8: 127-136.

16. Van de Vord R, Pogue K. Teaching Time Investment: Does Online Really Take More Time than Face-to-Face? International Review of Research in Open and Distance Learning 2012; 13 : 132-146.

17. Amir LR, Tanti I, Maharani DA, Wimardhani YS, Julia V, Benso Sulijaya B. etal. Student perspective of classroom and distance learning during COVID-19 pandemic in the undergraduate dental study program Universitas Indonesia. BMC Medical Education 2020; 20: 392.

18. Kumar LR, Bedra A, Karkera R. Perception of medical students on e-assessment conducted through Yengage portal. Arch Med Health Sci 2013; 1: 61-66.

19. Watson G, Sottile J. Cheating in the digital age: do students cheat more in online courses? Online Journal of Distance Learning Administration 2010; 13: 1-13.

20. Bettinger EP, Fox L, Loeb S, Tylor E S. Virtual classrooms: how online college courses affect student success. Am Econ Rev 2017; 107: 2855-2875.

21. Lorenzo-Alvarez R, Rudolphi-Solero T, Ruiz-Gomez MJ, Sendra-Portero F. Medical student education for abdominal radiographs in a $3 \mathrm{D}$ virtual classroom versus traditional classroom: a randomized controlled trial. AJR Am J Roentgenol 2019; 213: 644-650.

22. Mustafa GMM. The Acceptability of Online University degrees in the Arab Academia. 3rd International Conference For e-learning \& Distance Education; 2013. Riyadh, Saudi Arabia. [cited 2013]. Available from: https://www.researchgate.net/ publication/254864575

23. Parker K, Lenhart A, Moore K. The digital revolution and higher education: College presidents, public differ on value of online learning [cited 2011]. Avalible from: https://www.researchgate. net/publication/234655211_The_Digital_Revolution_and_ Higher_Education_College_Presidents_Public_Differ_on_ Value_of_Online_Learning

24. Esani M. Moving from Face-to-Face to Online Teaching. Clin Lab Sci 2010; 23: 187-203.

25. Chiasson K, Terras K, Smart K. Faculty perceptions of moving a face to face course to online instruction. Journal of College Teaching \& Learning (TLC) 2015; 12: 231-240.

26. Kamenetz, A. 'Panic-gogy': teaching online classes during the coronavirus pandemic. [cited 2020] Available from: https:// www.npr.org/2020/03/19/817885991/panic-gogy-teachingonline-classes-during-the-coronavirus-pandemic $\% 202020$. 